\title{
ENVIRONMENTAL LAW ENFORCEMENT IN THE PERSPECTIVE OF INDONESIA AND AUSTRALIA: CASE STUDY OF FOREST FIRES
}

\author{
${ }^{1}$ Wilda Prihatiningtyas \\ Faculty of Law, Airlangga University \\ Indonesia \\ wilda@fh.unair.ac.id \\ ${ }^{2}$ Zuhda Mila Fitriana \\ Faculty of Law, Airlangga University \\ Indonesia \\ zuhda.mila92@gmail.com
}

\author{
${ }^{3}$ Sophia Kusumawardhani \\ Faculty of Law, Airlangga University \\ Indonesia \\ socca.sophia@gmail.com
}

Abstract - Forest is recognized playing a crucial role in Earth's life circle, specifically in terms the existence of human beings. As year goes by, the area of forest has been decreased significantly due to deforestation. Human beings claims that they need wider space area to live, build a house and run a factory or create a plantation to support businesses. They intentionally fires some forest areas without eco-sustainability consideration. In Indonesia, particularly, the cases of forest fires have been considered at critical level. To add, most of forest fires cases are done intentionally by the suspects. Those actions thus negatively impact a massive scope of ecosystem. Specifically speaking, it is not forest fires that brings drawbacks to the ecosystem, but the haze itself. The massive dark haze as a result of forest fires certainly pollutes the air which causes some breathing system-related diseases. Simply said, the disadvantages of forest fires have been violating human beings welfare (against humanity) and therefore be considered as a criminal action. Globally speaking, intentional forest fires have been ruled under criminal code in some countries such as Canada and Australia. Moreover, in attempt to overcome forest fires issues, Food and Agriculture Organization of the United Nations (FAO) provides a guideline for national legal drafters regulating forest fires law. Accordingly, those who are accused by criminal codes will be punished pursuant to criminal penalties regulated. In the States of Victoria (Australia), for example, criminal penalties of intentional forest fires (arson) have been effectively sentenced. From 2007-2012, 73 people were sentenced in custodial type by judges. On the contrary, although Indonesia has been regulated criminal penalties for intentional forest fires actors, they seem less powerful and effective in practice. Recently, on July 2016, Riau's forest fires case was intentionally dissolved by Indonesian National Police Officer. This fact thus raises an issue as to whether Indonesian Criminal Penalties for intentional forest fires actors have been effectively applied. This research aims to discover and solve the aforementioned issue. As a positive attempt, authors expects that this research will provide some recommendations to create more effective sentencing systems for the suspects. Authors will use sustainable forestry principles. In the end, Authors are expecting Indonesia will be able to overcome its forest fires cases effectively and more efficient.

Keywords - Law Enforcement; Forest Fires.

\section{INTRODUCTION}

Forest and/or land fires are considered as one of potential threats for sustainable development due to its direct devastating impacts towards ecosystem, carbon emission, biodiversity, human health, economy sectors and global climate.[1] Due to the urgency of carbon emission (considered as trans-boundary haze disaster), South East Asia Countries (members of ASEAN) signed an Agreement of trans-boundary haze on June 2002 in Kuala Lumpur, Malaysia. Forest and/or land fires and its haze disaster becomes the utmost priority of the Indonesia Forestry Department due to the fact that those are happened in almost annual basis.

In 1997-98, the massive fires in Indonesia were on international headlines. As many foreign bodies were involved to extinguish the fires and caused a large amount of carbon emission, it was stated as the worst environmental disaster in century.[2] Five years after, regardless the significant awareness to prevent, lessen, and press the fires problems, Indonesia experienced high level of haze pollution reached between August-October 2002. Moreover, June 2013, transboundary haze problem affected Singapore and Malaysia as a result of land and/or forest fires in Sumatera and Borneo, Indonesia. Recently, in 2015, the massive fires and haze disaster has put Indonesia on International Headlines, once again. Between 2011 and 2016, more than 300,000 Ha of forest was burnt across Indonesia, reported by Ministry of Environment and Forestry of Indonesia. Central Borneo was placed at the first province which lost its forest in approximately 200,000 Ha alone in 2015, followed by South Sumatera which lost its 30,984 Ha area of forest.[3] Having observed, after 20 years, this problem is still far from solved in spite of a huge number of studies done by environmentalists. Policies ambiguity, less-environmentally-educated citizens, 
and blurry cause of fires are considered as the main ground of insignificant change.

Fires in Indonesia, to date, mostly occur on Indonesian tropical peat-lands and peat-swamp forests during dry seasons. Harrison states that, based on biological condition, it is almost unnatural for Indonesia to experience fires without any human involvement. It thus indicates that most of fires in Indonesia are man-made disasters. [4] Whilst in Australia, known as one of the fire-prone areas, has been threatened by natural forest fires for years. In early 2009, international media spot-lighted forest fires that killed over 180 people in Southern Australia. Not only killed almost 200 citizens, this also razed in approximate $0,5 \mathrm{Mha}$ of land. Both countries face similar problems in terms of forest fires that it is happened in annual basis. Yet, the causes of forest fires between both countries are slightly different. In Indonesia, again mentioned, forest fires are considered as a man-made disaster (e.g. uncontrolled deforestation). Whereas in Australia, intentional forest fires (arson) is not a main cause of forest fires. However, despite the natural threats of forest fires, Australia has a well fires management plan as depicted from its effective Arson Laws. Factually speaking, from 2007-2012, 73 arsonists in State of Victoria alone were sentenced in custodial basis. Unlike Australia, Indonesia has yet gone that far in sentencing arsonists. In other words, intentional forest fires laws has not well-enforced so far.

This paper analyzes Indonesia current Forestry-related Laws and its implication towards arsonists. Australian Forestry Laws and Regulation will be the subject of comparison. As a result, authors aim to provide distilled regulatory approaches that can be incorporated into the Forestry-related Laws sentencing and trial systems in Indonesia. Also, authors are expecting to give positive recommendation towards a better developed environment laws perspective.

\section{INDONESIAN'S FOREST FIRES POLICY: THE LOOPHOLE}

Indonesia is a an acrchipelagic state consisting of more than 17.508 islands of which 1000 are inhabited. The five biggest islands are Kalimantan ( 539,460 square $\mathrm{km} \mathrm{),}$ Sumatera ( 473,600 sqauare km ), Irian Jaya ( 422,981 square $\mathrm{km}$ ), Sulawesi ( 189,216 square $\mathrm{km}$ ) and Java ( 132,187 square $\mathrm{km}$ ). The archipelagic state is situated between 65 to 141 East of Greenwich ( longitude ) and $6 \mathrm{~N}$ to $11 \mathrm{~S}$ of the equator ( latitude). Seventy percent of the geographical area comprises waters, and the remaining $30 \%$ area is land.

The weather and climate of Indonesia are typical of equatorial or tropical regions. There are two seasons, namely, dry season (April - september) and rainy season (September April). The amount of tropical forest is around $47 \%$ of the land.

Indonesia is a unitary state which takes the form of republic. With regard to the administration, there are three levels of governments, namely, central level, provincial level and municipal level. The number of provinces , as well as municipalities, has been increasing due to political euphoria resulting from the changes of government since the middle of 1997. At present, there are 31 provinces and more than 500 munuicipalities and this number is expected to increase due to the growing demand for the implementation of more autonomous local governments ( municipal level ).

Environmental problem began to become a national issue in Indonesia in 1972 when Indonesia responded to and participated in the Stockholm Conference on Human environment. Three problems were indentified in accordance with the main topics of discussion for the 1972 conference on human environment, i.e. environmental problems of human settlements, management of natural resources and environmental pollution. [5]

The latest environmental problem in Indonesia was related to forest fire in Kalimantan and Sumatera which further caused serious transboundary air pollution. In this regard, Singapura launched a complaint against Indonesia, and would bring the the transboundary air pollution to the international level if the case was not seriously managed. However, the problem has so far been settled based upon $a$ spirit of ASEAN. The air pollutuion caused by forest fire in Indonesia has further posed the problem of Climate Change in ASEAN.

Locally, In Indonesia, forest fires become one of the priorities in disaster management boards. However, it only has one Law regulating forest fires in specific, Government Regulation No. 4/2001 concerning the Damage and/or Pollution of the Environment Control Related to Forest or Land Fires. Regarding to its level, based on Indonesian Source of Laws and Hierarchy of Laws, this legal instrument is placed on the third level. Therefore, its binding power is still less compared with Law and/or Government Regulation as Substitute.

Forest fires are mainly caused by human activities (land clearing for plantation and agriculture, land tenure's weapon, and resources extraction) [6] and natural consequences from long dry season. As a weapon in land tenure between two tribes or more, fires can be considered as arson. Unfortunately, there are some loopholes in Indonesian legal instruments to address such an issue: inconsistent regulation and unclear inter-institutions' authority distribution.

Not only focusing on central government regulation, forest fires issues shall be thoroughly examined by lower level of governance such as provincial until council government. In other words, to solve forest fire issues, collaborative work and well-coordinated relationship between governmental institutions are needed. After years, however, this ideal condition is still far from realization. Decentralization practices in Indonesia, somehow, are being applied ineffectively. By all mean, the linkage remains unclear as seen from contradictive legal products between central and regional governments. In this case, law makers at regional level usually set aside the old principle of lex superiori derograt legi inferiori. Pursuant to Art 11, legally speaking, this regulation prohibits any intentional forest fires in Indonesia for any purposes at any cost. On the contrary, Local Government Regulation (Central Borneo Regional) No. 5/2003, Art 2 (2) 
regulates: for special purposes and by permission, land clearing can be done by burning activities. It indicates that one of the loopholes is still existed and has not yet solved.

Furthermore, unclear responsibility and lack of authority distribution remain appearing in this legal instrument. Attempting to provide effective provisions by dividing authority between central, provincial, and municipal governments, this regulation's sector-based approach causes its ineffectiveness.[7] Two ministerial bodies mentioned in the definition part (Ministry of Environment and Ministry of Forestry) as law enforcer, yet only one is further authorized to enforce the law (Ministry of Forestry). Consequently, this creates a loophole triggering an issue as to which Ministry should supervise and control big business groups' attitudes towards land clearing (by burning peat-lands and peat-swamp forests). As a final result, without proper supervision and control, forest fires will hardly be controlled and prevented.[8]

\section{Australia's Forest Fires POLICY}

Considering Australia's geographical condition, landscape, Considering Australia's geographical condition, landscape, and weather condition, forest fire or bushfire is a common phenomenon. It is believed that Australia's landscapes and ecosystems have evolved and shaped by both historical and recent patterns of fire.[9] Since it is impossible to make the whole country fire-proof, the least they could do is to reduce the occurrence, severity, and impact of forest fires through a national bushfire management policy. This policy is based on the vision that:

Fire regimes are effectively managed to maintain and enhance the protection of human life and property, and the health, biodiversity, tourism, recreation and production benefits derived from Australia's forests and rangelands. [10]

Basically, they conduct two types of bushfire management, which are fire fighting and fire prevention.

Based on The Australian Capital Territory Strategic Bushfire Management Plan (ACT SBMP), there are 12 objectives and strategies to reduce the risk and consequences of forest and bushfire; those are:[11]

1. a reduction in bushfire ignitions;

2. effective firefighting operations by skilled and motivated personnel;

3. the necessary equipment and resources to respond to and extinguish bushfires;

4. extinguish bushfires when they occur;

5. planned fire management on rural lands;

6. broad area bushfire fuel reduction across the natural and rural landscape of the ACT;

7. access for vehicles and firefighters to undertake bushfire fighting and fuel reduction;

8. adaptive management to provide continuous improvement in bushfire management;

9. a community that is prepared for bushfires;
10. effective land-use policy and planning that reduces bushfire risk;

11. integrated measures for bushfire protection at the urban edge; and

12. the community and government recover from the effects of bushfires.

These objectives and strategies are the improved version of the 2004 SBMP. A clear distribution of authority between the Australian Government, state and territory governments, and local governments enhance Australia's forest fire management. Under ACT SBMP, there is Regional Fire Management Plan (RFMP) which provides a further and more detailed bushfire operational plan(s) (BOPs) in accordance with its regional characteristics. Both the ACT SBMP and RFMP are made every five years. Furthermore, it should be noted that he RFMP shall not contradict the ACT SBMP. In other words, they have to have a well-synchronized and harmonized legal instrument.

Beside the comprehensive legislation, planning and coordination, one of the key points to Australia's fire management plan effectiveness is the community resilience as well as preparedness for bushfires. Eve Coles and Philip Buckle emphasize that effective recovery (from disaster) can be achieved only where the affected community participates fully in the recovery process and where it has the capacity, skills, and knowledge to make its participation meaningful.[12] Although this participation tends to happen spontaneously after a disaster, it can also be planned or developed beforehand.

\section{RECOMMENDATIONS}

After comparing the forest fire management of both Indonesia and Australia, the authors suggest for the Government of Indonesia to: First, synchronize and harmonize Legal Instruments of Forest Management. Second, develop well-managed inter-institutions relation by establishing One Roof Environmental System (ORES) between all ministerial of environmental-related matters, legal prosecutor, and police. Third, encourage community participation in the prevention and recovery process of forest fire.

\section{REFERENCES}

[1] Harrison et.al, The global impact of Indonesian forest fires, Biologist, Volume 56 Number 3, August 2009, p. 157

[2] Luca Tacconi, Kebakaran Hutan di Indonesia: Penyebab, Biaya dan Implikasi Kebijakan, CIFOR Occasional Paper No. 38(i), 2003.

[3] Karhutia Monitoring System Report <sipongi.menlhk.go.id> Directorate PKHL Ministry of Environment and Forestry of Indonesia. 
[4] Asian Development Bank, 'Planning for Fire Prevention and Drought Management Project' (Working Paper 1, April 1999)

[5] Siti Sundari Rangkuti. 2005. Hukum Lingkungan dan Kebijaksaan Lingkungan Nasional. Airlangga University Press. Cetakan ketiga, Surabaya, p. 59-60.

[6] Qodriyatun, Sri Nurhayati, 'Kebijakan Penanganan Kebakaran Hutan dan Lahan', Info Singkat Kesejahteraan Sosial Vol. VI, No. 06/II/P3DI/Maret/2014

[7] Nurrochmat, 'Antisipasi Bencana, Dinanti UU Kebakaran Hutan', Kompas (Jakarta), 6 Septemper 2011

[8] BBC News, 'World: Analysis Haze - Who Starts the Fires? (4 July 1998)

[9] Forest Fire Management Group, 2014, National Bushfire Management Policy Statement for Forests and Rangelands,

<http://www.sfmc.tas.gov.au/sites/sfmc.tas.gov.au/files/N ationalBushfireManagementPolicy_2014.pdf>, accessed on December 12, 2017, pg 18

[10] Forest Fire Management Group, 2014, National Bushfire Management Policy Statement for Forests and Rangelands,

$<$ http://www.sfmc.tas.gov.au/sites/sfmc.tas.gov.au/files/N ationalBushfireManagementPolicy_2014.pdf $>$, accessed on December 12, 2017, pg 9

[11] The ACT Strategic Bushfire Management Plan 2014 2019, P. 8 - 9

[12] Coles, Eve and Buckle, Philip. Developing Community Resilience as a Foundation for Effective Disaster Recovery [online]. Australian Journal of Emergency Management, The, Vol. 19, No. 4, Nov 2004: 6-15. Availability: $<$ https://search.informit.com.au/documentSu mmary;dn=375435145094637;res=IELHSS > ISSN:

1324-1540. [cited 21 Dec 17]. 